\title{
Life-cycle-assessment of the historical development of air pollution control and energy recovery in waste incineration
}

\author{
Damgaard, Anders; Riber, C.; Fruergaard, Thilde; Hulgaard, T.; Christensen, Thomas Højlund
}

Published in:

Waste Management

Link to article, DOI:

10.1016/j.wasman.2010.03.025

Publication date:

2010

Document Version

Peer reviewed version

Link back to DTU Orbit

Citation (APA):

Damgaard, A., Riber, C., Fruergaard, T., Hulgaard, T., \& Christensen, T. H. (2010). Life-cycle-assessment of the historical development of air pollution control and energy recovery in waste incineration. Waste Management, 30(7), 1244-1250. https://doi.org/10.1016/j.wasman.2010.03.025

\section{General rights}

Copyright and moral rights for the publications made accessible in the public portal are retained by the authors and/or other copyright owners and it is a condition of accessing publications that users recognise and abide by the legal requirements associated with these rights.

- Users may download and print one copy of any publication from the public portal for the purpose of private study or research.

- You may not further distribute the material or use it for any profit-making activity or commercial gain

- You may freely distribute the URL identifying the publication in the public portal 
Accepted for publication in Waste management

\title{
Life-cycle-assessment of the historical development of air pollution control and energy recovery in waste incineration
}

\author{
Anders Damgaard $^{1}$, Christian Riber ${ }^{2}$, Thilde Fruergaard ${ }^{1}$, Tore Hulgaard ${ }^{2} \&$ Thomas \\ H. Christensen ${ }^{1}$ \\ ${ }^{1}$ Department of Environmental Engineering \\ Technical University of Denmark \\ Miljoevej, Building 113, DK-2800 Kongens Lyngby \\ Denmark \\ ${ }^{2}$ Ramboll, Consulting Engineers \\ Teknikerbyen 31, DK 2830 Virum \\ Denmark \\ * Corresponding author: \\ Phone: +4545251602 \\ Fax: +4545932850 \\ E-mail: and@env.dtu.dk
}

"NOTE: this is the author's version of a work that was accepted for publication in Waste Management journal. Changes resulting from the publishing process, such as peer review, editing, corrections, structural formatting, and other quality control mechanisms may not be reflected in this document. Minor changes may have been made to this manuscript since it was accepted for publication. A definitive version is published in Waste management, vol 30(7), pp 1244-1250, doi:

10.1016/j.wasman.2010.03.025" 


\section{Abstract}

Incineration of municipal solid waste is a debated waste management technology. In some countries it is the main waste management option whereas in other countries it has been disregarded. The main discussion point on waste incineration is the release of air emissions from the combustion of the waste, but also the energy recovery efficiency has a large importance. The historical development of air pollution control in waste incineration was studied through life cycle assessment modelling of eight different air pollution control technologies. The results showed a drastic reduction in the release of air emissions and consequently a significant reduction in the potential environmental impacts of waste incineration. Improvements of a factor 0.85-174 were obtained in the different impact potentials as technology developed from no emission control at all, to the best available emission control technologies of today (2010). The importance of efficient energy recovery was studied through seven different combinations of heat and electricity recovery, which were modelled to substitute energy produced from either coal or natural gas. The best air pollution control technology was used at the incinerator. It was found that when substituting coal based energy production total net savings were obtained in both the standard and toxic impact categories. However, if the substituted energy production was based on natural as, only the most efficient recovery options yielded net savings with respect to the standard impacts. With regards to the toxic impact categories, emissions from the waste incineration process were always larger than those from the avoided energy production based on natural gas. The results shows that the potential environmental impacts from air emissions have decreased drastically during the last 35 years and that these impacts can be partly or fully offset by recovering energy which otherwise should have been produced from fossil fuels like coal or natural gas. 


\section{Introduction}

Incineration of municipal solid waste is debated as a waste management disposal option. Countries such as Switzerland, Japan and Denmark incinerate more than $65 \%$ of the municipal solid waste, while other countries like the UK and USA often have disregarded waste incineration in decisions on future waste management systems. In recent years this has though changed and a number of plants are under construction or being planned in the UK and USA. In addition to costs, the air pollution aspects of waste incineration are often the main argument against waste incineration.

Riber et al. (2008) presented a model for assessing the environmental aspects of waste incineration arguing that direct as well as indirect emissions should be accounted. The direct emissions are primarily the release through the stack of air emissions from the combustion of the waste. The indirect emissions could be avoided emissions since waste incineration usually produces energy that otherwise should have been produced from other types of fuels. This suggests that the overall environmental impacts from waste incineration will depend on the flue gas cleaning technology reducing the amounts of pollutants released through the incinerator stack to the atmosphere as well as the amount of energy produced and the savings obtained by avoiding the production of the same amount of energy by conventional power plants.

The purpose of this paper is to assess and quantify the environmental importance of the development of air pollution control (APC) of waste incineration by means of life-cycle-assessment (LCA) considering various flue gas cleaning technologies, and to assess the substitutional value of the energy potentially produced by incineration of the waste. The EASEWASTE model presented by Kirkeby et al. (2006) and Riber et al. (2008) was applied to incineration of municipal waste by considering incineration 
with increasing degrees of flue gas cleaning as well as energy recovery. This provides an integrated perspective on air pollution and energy recovery aspects of solid waste incineration.

\section{The EASEWASTE incineration module}

The EASEWASTE model encompasses two kinds of air emissions from waste incineration: process-specific and input-specific emissions. Process-specific emissions are quantified as amount of air pollutants in $\mathrm{kg}$ per tonne of waste incinerated and are typically pollutants generated or released as a function of the operation of the furnace or the air pollution control system (e.g. CO, dioxins and $\mathrm{HCl}$ ). Input-specific emissions are quantified by a transfer coefficient specifying how much of the input by mass (the mass of pollutant included in the waste) is transferred to the stack emissions, and to the solid outputs (APC residues, bottom ashes, etc.). Transfer coefficients typically apply to heavy metals. Riber et al. (2008) describes the model in detail.

The consumption of energy and ancillary materials by the incineration plant (electricity, natural gas, diesel fuel, biomass, activated carbon etc.) is specified per tonne of waste incinerated, while the energy recovered is expressed as a percentage of the net calorific value of the waste incinerated. The environmental impacts associated with these consumptions and substitutions are calculated based on the environmental profiles (life cycle inventories) of these materials and fuels.

\section{Waste incineration technologies: Air emissions}

To illustrate the development over time in waste incineration technology with respect to flue gas cleaning, eight air-pollution-control technologies (APC 1-8) were 
considered for incineration of the same type of municipal waste. The different technologies can to some extent be attributed to the Danish Environmental Protection Law proposed in 1973 and following executive orders to this law, which have set increasingly stricter regulations on emission limits for waste incineration. From 1989 air emission requirements have been in accordance with the actual EU Waste incineration directive the latest being European Parliament (2000); the EU WID limit values are included in Table 1 for comparison. Each APC technology is briefly described below where also the approximate period each APC technology was used in plants in Denmark is shown, which:

- APC 1: No flue gas cleaning - before 1973

- APC 2: Simple flue gas cleaning by an electrostatic precipitator that primarily removes particles and associated pollutants - from 1970 to 1989

- APC 3: Semidry flue gas cleaning with injection of lime (no activated carbon) and subsequently removal of particles in a baghouse filter - from 1989 to 2004

- APC 4: Wet flue gas cleaning following particle removal in an electrostatic precipitator. This system provides wet scrubbing in an acidic scrubber system and subsequent wastewater cleaning - from 1989 to 2004

- APC 5: Semidry flue gas cleaning (as APC 3 but with increased efficiency) with addition of activated carbon and selective non-catalytic reduction (SNCR) of nitrogen oxide (de-nitrification $\left(\mathrm{deNO}_{\mathrm{x})}\right)$ - from 2004

- APC 6: Wet flue gas cleaning (as described above in APC 4) with an additional alkaline scrubber followed by a bag house filter with activated carbon injection for removal of dioxin and mercury and SNCR for deNO $\mathrm{X}_{\mathrm{X}}-$ from 2000

- APC 7: Semidry flue gas cleaning and dioxin filter (as described above in APC 5) followed by flue gas condensation and selective catalytic reduction (SCR) instead 
of SNCR for nitrogen oxide removal (deNOx) -from 2008

- $\quad$ APC 8: Wet flue gas cleaning and dioxin filter (as described above APC 6)

followed by flue gas condensation and SCR instead of SNCR for $\mathrm{deNO}_{\mathrm{X}}-$ from 2004

The "no-flue-gas-cleaning" technology is of course not a real alternative today, but it serves here as a reference that may represent waste incineration technology known from the fifties and sixties of the last century. In an EU context neither APC 2, 3 and 4 technologies would fulfil current legal requirements of today (2010).

The emissions assumed for the various technologies are presented in Table 1. The emissions are best estimates based on our experiences in flue gas cleaning and measurements on several Danish waste incineration plants (see for example Riber et al., 2005). No actual data exist from incineration plants that differ only in their flue gas cleaning system, thereby excluding the possibility of basing a comparative set of data on actual measurements. Usually also the waste composition (see e.g. Riber et al., 2005) and the combustion technology vary among plants and over time. The data presented in Table 1 represent typical air emissions based on the same waste composition assuming that a constant fraction of the pollutants are transferred to the bottom ash, while the remaining part in various degrees - and depending on the APC technology - are transferred to the stack as an air emission or to the APC residues. The data are best estimates based on (unpublished) measurements from a number of plants and experiences on obtainable process guarantees from contracts of APC installations. The sequence of the APC technologies illustrates a likely decrease in air emissions as the flue gas cleaning technology is improving. 
Table 1 Air emissions estimated for municipal waste incineration with increasing degree of flue gas cleaning. EU WID limit values included based on European Parliament (2000) for comparison.

\begin{tabular}{|c|c|c|c|c|c|c|c|c|c|}
\hline $\begin{array}{l}\text { Flue gas cleaning } \\
\text { technology }\end{array}$ & $\begin{array}{l}\mathrm{EU}^{1} \\
\text { WID }\end{array}$ & $\begin{array}{c}\text { APC } \\
1 \\
\end{array}$ & $\begin{array}{c}\text { APC } \\
2 \\
\end{array}$ & $\begin{array}{c}\mathrm{APC} \\
3\end{array}$ & $\begin{array}{c}\mathrm{APC} \\
4\end{array}$ & $\begin{array}{c}\mathrm{APC} \\
5\end{array}$ & $\begin{array}{c}\text { APC } \\
6\end{array}$ & $\begin{array}{c}\text { APC } \\
7\end{array}$ & $\begin{array}{c}\text { APC } \\
8\end{array}$ \\
\hline \multicolumn{10}{|l|}{ Technical configuration } \\
\hline Particle removal & - & No & Yes & Yes & Yes & Yes & Yes & Yes & Yes \\
\hline Scrubbing $^{2}$ & - & No & No & Dry & Wet & Dry & Wet & Dry & Wet \\
\hline Dioxin filter & - & No & No & No & No & Yes & Yes & Yes & Yes \\
\hline Flue gas condensation & - & No & No & No & No & No & No & Yes & Yes \\
\hline $\operatorname{deNO}_{x}-$ technology & - & No & No & No & No & SNCR & SNCR & SCR & SCR \\
\hline \multicolumn{10}{|l|}{ Energy use } \\
\hline $\begin{array}{l}\text { Electricity consumption for } \\
\text { operation of APC system } \\
\text { (kWh per tonne of waste) }\end{array}$ & - & 10 & 30 & 40 & 60 & 45 & 70 & 75 & 80 \\
\hline
\end{tabular}

\section{Material use}

( $\mathrm{kg}$ per tonne of waste)

Activated carbon

Ammonia water

$\mathrm{CaCO}_{3}$

$\mathrm{FeCl}_{3}$

Hydrated lime $\mathrm{Ca}(\mathrm{OH})_{2}$

$\mathrm{NaOH}$

Polymer

TMT-15

Water $\left(\mathrm{m}^{3} /\right.$ tonne $)$

\begin{tabular}{ccccccccc}
- & - & - & - & - & 0.5 & 0.5 & - & - \\
- & - & - & - & - & 2.4 & 2.4 & 3.3 & 3.3 \\
- & - & - & - & 5.8 & - & 7.1 & - & 7.3 \\
- & - & - & - & 0.06 & - & 0.06 & - & 0.06 \\
- & - & - & 6.7 & - & 11.9 & - & 10.0 & - \\
- & - & - & - & 0.3 & - & 0.4 & 1.5 & 0.4 \\
- & - & - & - & 0.01 & - & 0.01 & - & 0.01 \\
- & - & - & - & 0.04 & - & 0.04 & - & 0.04 \\
- & - & - & 0.1 & 0.30 & 0.2 & 0.20 & - & 0.06 \\
\hline
\end{tabular}

\section{Air emissions}

(g per tonne of waste)

\begin{tabular}{lccccccccc}
$\mathrm{SO}_{2}$ & 273 & 1,100 & 1,100 & 270 & 870 & 164 & 109 & 55 & 27 \\
$\mathrm{HCl}$ & 55 & 3,800 & 3,800 & 110 & 27 & 27 & 11 & 5 & 3 \\
$\mathrm{NOx}$ & 2730 & 2,200 & 2,200 & 2,200 & 2,200 & 900 & 900 & 55 & 55 \\
$\mathrm{NH}_{3}$ & - & 3 & 3 & 3 & 0 & 40 & 1 & 16 & 16 \\
$\mathrm{Particles}$ & 164 & 8,200 & 400 & 55 & 55 & 11 & 11 & 5 & 5 \\
$\mathrm{Hg}$ & 0.28 & 0.82 & 0.82 & 0.11 & 0.11 & 0.005 & 0.05 & 0.003 & 0.003 \\
$\mathrm{~Pb}$ & $2.7^{1}$ & 82 & 5 & 1.1 & 1.1 & 0.5 & 0.5 & 0.11 & 0.11 \\
$\mathrm{Cd}$ & 0.27 & 5 & 1.1 & 0.16 & 0.16 & 0.11 & 0.05 & 0.01 & 0.01 \\
$\mathrm{As}$ & $2.7^{1}$ & 3 & 0.5 & 0.16 & 0.16 & 0.11 & 0.05 & 0.01 & 0.01 \\
$\mathrm{CO}_{2}$ fossil $^{3}$ (kg/tonne) & - & 300 & 300 & 300 & 300 & 300 & 300 & 300 & 300 \\
Dioxin $^{4}(\mu \mathrm{g} /$ tonne) & 0.55 & 16 & 16 & 3 & 11 & 0.3 & 0.3 & 0.11 & 0.11 \\
\hline
\end{tabular}

Solid outputs ${ }^{5}$

(kg per tonne of waste)

Fly ash

Mixed solid APC residue

Wastewater $\left(\mathrm{m}^{3} /\right.$ tonne $)$

Gypsum (90\% dry solids)

Sludge with heavy metals

$\begin{array}{ccccccccc}- & - & 7.8 & - & 8.1 & - & 8.2 & - & 8.2 \\ - & - & - & 19.8 & - & 25.8 & - & 23.6 & - \\ - & - & - & - & 0.08 & - & 0.10 & 0.04 & 0.10 \\ - & - & - & - & - & - & 2.9 & - & 3.2 \\ - & - & - & - & 1.5 & - & 2.0 & - & 1.5\end{array}$

' $:$ The EU WID limit values have been converted based on an assumption of $5460 \mathrm{~m} 3$ flue gas/tonne waste. $\mathrm{Pb}$ and $\mathrm{As}$ are the value for the combined amount of $\mathrm{Sb}+\mathrm{As}+\mathrm{Pb}+\mathrm{Cr}+\mathrm{Co}+\mathrm{Cu}+\mathrm{Mn}+\mathrm{Ni}+\mathrm{V}$

2: Acid gas absorption is for illustration assumed to be hydrated lime and limestone for semi-dry and wet systems, respectively. ${ }^{3}$ After Astrup, 2009.

4: TEQ (toxicity equivalents), international, cf. Directive 2000/76/EC of the European Parliament and of the Council of 4 December 2000 on the Incineration of Waste.

5: Solid outputs are included for illustration, but not included in the modelling as explained in the text. 
The solid waste is assumed to be municipal solid waste, being a mixture of household waste, commercial waste and waste from civic amenity sites. Main constituents are, paper, cardboard, food waste, plastics (hard and soft types), wood, glass and metal. The net calorific value of the waste was assumed as $10 \mathrm{MJ}$ per $\mathrm{kg}$ waste wet weight. For the sake of uniformity, the same waste composition was assumed for all incineration scenarios APC1-8. The increase in use of ancillary materials (sodium hydroxide, activated carbon, ammonia etc) in the advanced APC technologies was also included.

The treatment of the solid outputs from the incinerator was not included. The reason for this is not that these outputs are not important, but the main concern with regards to waste incineration is emissions coming out of the stack as these emissions are not controllable once released and can cause harm to humans and environment. The solid outputs on the other hand can be controlled and can either be upgraded and utilized or sent to a secure disposal site for final storage. Similarly, liquid effluents may be cleaned to a level that makes the mass flow of pollutants insignificant.

\section{Waste incineration technologies: Energy recovery and substitution}

\subsection{Energy recovery}

In addition to controlling the air emissions from waste incineration it is equally important to recover the energy, since this can substitute energy that otherwise would have to be produced elsewhere. In order to illustrate the development in energy recovery from waste incineration seven incineration scenarios with increasing energy recovery were established (ER 1-7). The energy use of the incineration scenarios are 
accounted separately, i.e. the shown values are gross values not including the energy use of the plant:

- ER 1: No energy recovery

- ER 2: Energy recovery in terms of electricity at a moderate rate corresponding to $24 \%$ of the net calorific value of the waste

- ER 3: Energy recovery in terms of electricity at a maximum rate corresponding to $30 \%$ of the net calorific value of the waste

- ER 4: Energy recovery in terms of electricity and heat at a moderate rate corresponding to $19 \%$ of the net calorific value as electricity and $56 \%$ as heat

- ER 5: Energy recovery in terms of electricity and heat at a maximum rate corresponding to $27 \%$ of the net calorific value as electricity and $65 \%$ as heat

- ER 6: Energy recovery in terms of electricity and heat at a moderate rate corresponding to $22 \%$ of the net calorific value as electricity and $69 \%$ as heat including simple flue gas condensation by heat exchange with district heating water

- ER 7: Energy recovery in terms of electricity and heat at a maximum rate corresponding to $24 \%$ of the net calorific value as electricity and $83 \%$ as heat including advanced flue gas condensation by an absorption heat pump

The data in Table 2 is acquired by comparing operational data from existing wasteto-energy plants and knowledge of possible efficiencies given by different suppliers of boiler and energy conversion technologies. The technologies in Table 2 represent typical plants in operation in a past or present European context and do not necessarily represent any specific plant. The boiler efficiency describes how much of the energy content of the waste is recovered in total. The boiler heat recovery rate 
states how much of this energy is recovered in form of heat, and the gross electricity rate how much is converted to electricity.

Table 2 Applied energy recovery rates for waste incinerators. All efficiencies are in \% of waste energy content on the basis of net calorific value.

\begin{tabular}{|c|c|c|c|c|c|c|c|}
\hline $\begin{array}{l}\text { Energy recovery } \\
\text { technology }\end{array}$ & ER1 & ER2 & ER3 & ER4 & ER5 & ER6 & ER7 \\
\hline Recovery scenario & No & Moderate & Maximum & Moderate & Maximum & Moderate & Maximum \\
\hline Boiler efficiency & No & 75 & 92 & 75 & 92 & 86 & 92 \\
\hline $\begin{array}{l}\text { Boiler heat recovery } \\
\text { rate }\end{array}$ & No & No & No & 56 & 65 & 64 & 67 \\
\hline $\begin{array}{l}\text { Heat by flue gas } \\
\text { condensation }\end{array}$ & No & No & No & No & No & 5 & 15 \\
\hline $\begin{array}{l}\text { Gross electricity } \\
\text { recovery rate }\end{array}$ & No & 24 & 30 & 19 & 27 & 22 & 24 \\
\hline $\begin{array}{l}\text { Own electricity } \\
\text { consumption }\end{array}$ & 2 & 3 & 3 & 3 & 3 & 4 & 4 \\
\hline $\begin{array}{l}\text { Net electricity } \\
\text { recovery rate }\end{array}$ & -2 & 21 & 27 & 16 & 24 & 18 & 20 \\
\hline $\begin{array}{l}\text { Net heat recovery } \\
\text { rate }\end{array}$ & 0 & 0 & 0 & 56 & 65 & 69 & 83 \\
\hline
\end{tabular}

\subsection{Energy substitution}

The environmental value of the energy recovered depends primarily on the type of energy production avoided; meaning which power plant will produce less energy or which type of power plant will not be built in the future if energy is being delivered by the incinerator. This again may depend on many factors such as the current energy producing facilities, exchange of energy between markets and also on the time frame considered. Is it a spot market response that is modelled or is it the consequences of long term planning of the energy sector giving priority to electricity or heat produced by waste incineration? All these issues may vary considerably among countries and regions, but in order to keep focus on the main issues it is assumed that the marginal energy mix used by the plant as well as the energy production avoided is coal based or natural gas based energy production.

Table 3 presents the air emissions associated with heat and electricity production from coal and natural gas, respectively. Emissions are allocated based on energy 
content in case of co-production of electricity and heat. The importance of electricity and heat production are thereby similar $(1 \mathrm{kWh}$ electricity $=1 \mathrm{kWh}$ heat $)$. Emissions describing combined heat and power (CHP) production are therefore identical for electricity and heat. These issues are elaborated in Fruergaard et al. (2009). The coal based CHP data are an average of emissions from various Danish plants. The natural gas based CHP technology is based on data from a study by Nielsen \& Illerup (2003) and recovery efficiencies are based on new Danish CHP plants. The coal based electricity generating technology with no heat recovery is based on data from a Danish power plant producing electricity only. The electricity generating technology with no heat recovery based on natural gas is also from the study of Nielsen and Illerup (2003). Extraction of coal and gas are based on data from the Danish EDIP database (EDIP, 2004).

Table 3 Air emission factors ascribed to energy production in conventional energy producing facilities. The unit is kg per kWh energy (electricity or heat) delivered. Allocation based on energy content.

\begin{tabular}{lcccc}
\hline $\begin{array}{l}\text { Energy } \\
\text { production }\end{array}$ & \multicolumn{2}{c}{ Electricity only } & \multicolumn{2}{c}{ Combined heat and power } \\
\hline Fuel type & Coal & Gas & Coal & Gas \\
\hline Air emissions & $\mathrm{kg} / \mathrm{kWh}$ & $\mathrm{kg} / \mathrm{kWh}$ & $\mathrm{kg} / \mathrm{kWh}$ electricity & $\mathrm{kg} / \mathrm{kWh}$ electricity or \\
electricity & electricity & or heat & heat \\
$\mathrm{CO}_{2}$ & $9.81 \mathrm{E}-1$ & $4.86 \mathrm{E}-1$ & $5.99 \mathrm{E}-1$ & $2.51 \mathrm{E}-1$ \\
$\mathrm{CO}$ & $2.23 \mathrm{E}-4$ & $6.37 \mathrm{E}-5$ & $1.30 \mathrm{E}-4$ & $3.28 \mathrm{E}-5$ \\
$\mathrm{SO}_{2}$ & $7.24 \mathrm{E}-4$ & $9.39 \mathrm{E}-6$ & $3.74 \mathrm{E}-4$ & $4.99 \mathrm{E}-6$ \\
$\mathrm{HCl}$ & $9.07 \mathrm{E}-6$ & $1.07 \mathrm{E}-7$ & $6.68 \mathrm{E}-6$ & $5.52 \mathrm{E}-8$ \\
$\mathrm{NOx}$ & $2.72 \mathrm{E}-3$ & $1.11 \mathrm{E}-3$ & $1.02 \mathrm{E}-3$ & $5.76 \mathrm{E}-4$ \\
$\mathrm{~N}_{2} \mathrm{O}$ & $9.36 \mathrm{E}-6$ & $2.13 \mathrm{E}-5$ & $5.66 \mathrm{E}-6$ & $1.10 \mathrm{E}-6$ \\
$\mathrm{CH}$ & $5.65 \mathrm{E}-3$ & $1.75 \mathrm{E}-5$ & $3.37 \mathrm{E}-3$ & $9.01 \mathrm{E}-6$ \\
$\mathrm{Particles}$ & $1.04 \mathrm{E}-4$ & $4.97 \mathrm{E}-6$ & $4.96 \mathrm{E}-5$ & $2.56 \mathrm{E}-6$ \\
$\mathrm{Hg}$ & $1.38 \mathrm{E}-8$ & $1.47 \mathrm{E}-12$ & $8.86 \mathrm{E}-9$ & $7.54 \mathrm{E}-13$ \\
$\mathrm{~Pb}$ & $1.33 \mathrm{E}-8$ & $5.03 \mathrm{E}-12$ & $4.55 \mathrm{E}-9$ & $2.59 \mathrm{E}-12$ \\
\hline
\end{tabular}

\section{Environmental impact assessment}

The functional unit used in the study is treatment of one tonne of waste by incineration. Table 4 presents the impact categories that EASEWASTE use in order to aggregate all the quantified emissions to air, soil and surface water. The impact categories are based on the EDIP 97 method (Wenzel et al., 1997). 
Table 4 Potential impact categories included in EASEWASTE (after Kirkeby et al., 2006).

Normalization references after Stranddorf et al. (2005).

\begin{tabular}{|c|c|c|c|c|}
\hline $\begin{array}{l}\text { Potential impact } \\
\text { category }\end{array}$ & Acronym & Unit & $\begin{array}{c}\text { Physical } \\
\text { basis }\end{array}$ & $\begin{array}{l}\text { Normalization } \\
\text { reference } \\
\text { EU-15 }\end{array}$ \\
\hline $\begin{array}{l}\text { Global Warming, } 100 \\
\text { years }\end{array}$ & GW & $\mathrm{Kg} \mathrm{CO}_{2}$-eq. $/$ person/yr & Global & 8,700 \\
\hline $\begin{array}{l}\text { Photochemical Ozone } \\
\text { Formation }\end{array}$ & POF & $\mathrm{kg} \mathrm{C}_{2} \mathrm{H}_{4}$-eq. /person/yr & Regional & 25 \\
\hline Acidification & $\mathrm{AC}$ & $\mathrm{kg} \mathrm{SO}_{2}$-eq. /person/yr & Regional & 74 \\
\hline Nutrient Enrichment & $\mathrm{NE}$ & $\mathrm{kg} \mathrm{NO}_{3}{ }^{-}$eq. $/$person/yr & Regional & 119 \\
\hline Human Toxicity, soil & HTs & $\mathrm{m}^{3}$ soil /person/yr & Regional & 157 \\
\hline Human Toxicity, water & HTw & $\mathrm{m}^{3}$ water /person/yr & Regional & 179,000 \\
\hline Human Toxicity, air & HTa & $\mathrm{m}^{3}$ air /person/yr & Regional & $2,090,000,000$ \\
\hline Ecotoxicity, soil & ETs & $\mathrm{m}^{3}$ water /person/yr & Regional & 964,000 \\
\hline $\begin{array}{l}\text { Ecotoxicity, water } \\
\text { chronic }\end{array}$ & ETwc & $\mathrm{m}^{3}$ water /person/yr & Regional & 352,000 \\
\hline
\end{tabular}

Table 4 also presents the latest normalization references (Stranddorf et al., 2005)

used to convert the individual potential impact categories into person equivalents (PE).

$\mathrm{PE}$ is an average value for the yearly contribution to that impact category by all the activities and consumptions of one person. It may seem problematic to use normalization references from 2005 for a technology as it was designed in the 1970s, but the purpose is to show what the impact would be if a technology like this was used today. It is therefore found to be a valid approach.

The potential environmental impacts in the assessment are divided into "standard potential impacts" and "toxicity-related potential impacts".

Standard potential impacts include global warming, acidification, photochemical ozone formation and nutrient enrichment. The methodologies utilized for the assessment of these environmental impacts are well-acknowledged, although different characterization factors may appear in different methods. The degree of certainty of the potential impacts can be considered high. Incineration of all carbon-containing waste will produce $\mathrm{CO}_{2}$, but only waste containing fossil carbon (primarily plastic products and textiles) is considered to contribute to global warming. Food and paper products originate from organic material, which has been photo-synthesized on 
atmospheric $\mathrm{CO}_{2}$. Combustion of these products is thus in LCA-terms considered $\mathrm{CO}_{2}$-neutral (Christensen et al., 2009). In the comparison of the APC technologies it was assumed that the global warming from the combustion of the waste itself contributed with $300 \mathrm{~kg} \mathrm{CO} 2$ of fossil origin per tonne waste (Astrup, 2009). The difference in global warming for the 8 scenario's is therefore only due to the use of energy and auxiliary materials in the air pollution control system.

Toxicity-related potential impacts include human toxicity via soil, water and air as well as eco-toxicity in soil and in water. The degree of certainty of the toxicity-related impact potentials is lower than of the standard impacts since the utilized methodology is still being developed and tested. However, these impacts are included since it is especially these impacts that are considered of a high relevance with regards to combustion of municipal solid waste. 


\section{Results and discussion}

\subsection{APC technologies}

The results of the modelling of the eight incineration scenarios with increasing APC technology efficiency is seen in Figure 1.

Figure 1 The environmental impacts for the APC1-APC8 given in Person Equivalent (PE).
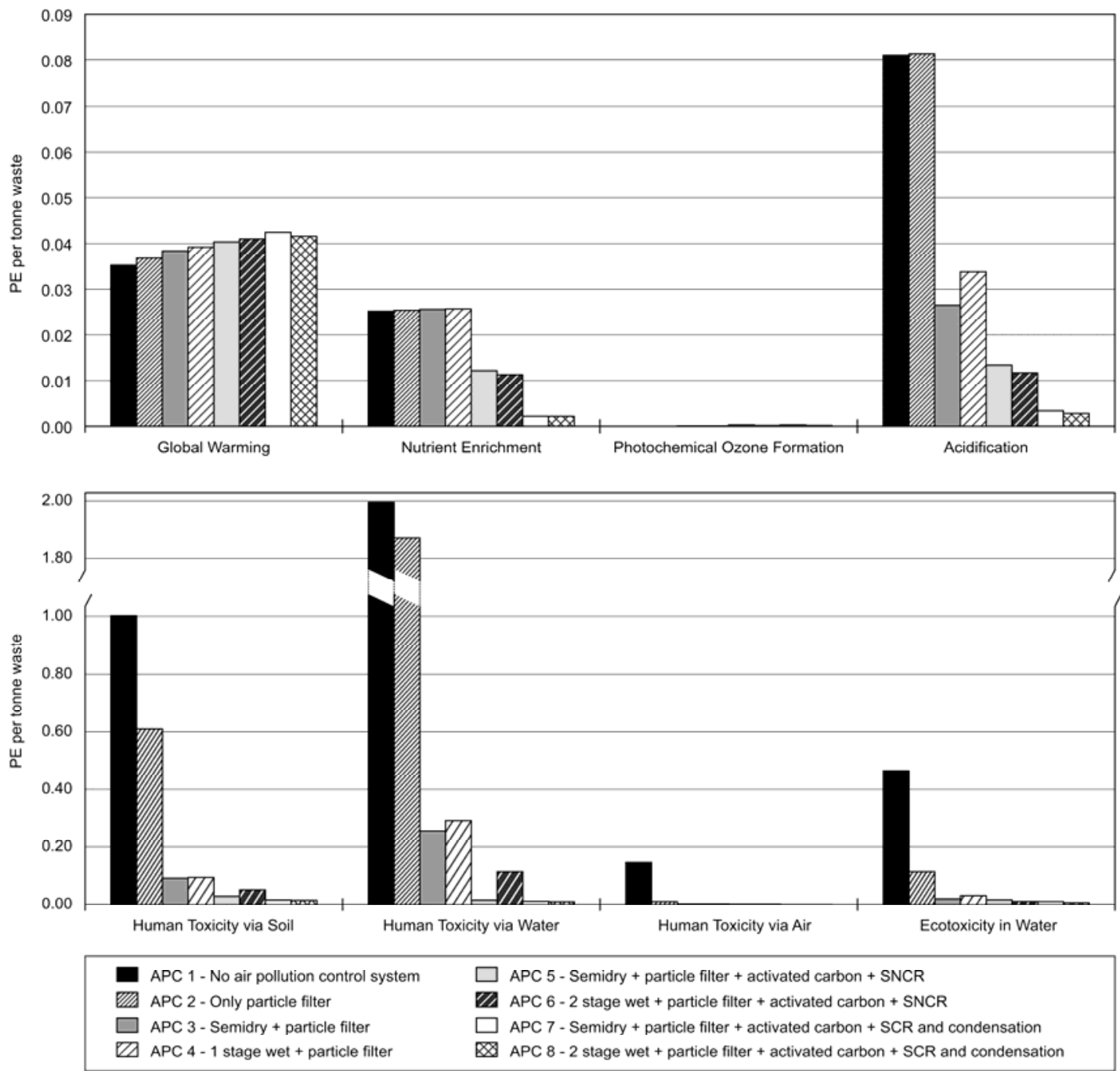

The figure clearly shows that there has been a massive development from the early incinerators of the seventies and till today's modern incinerators with extensive air pollution control. It is seen that all impact potentials have been considerably reduced; especially the toxic impacts have decreased dramatically. As an example, the acidification potential has improved from $0.08 \mathrm{PE}$ to $0.003 \mathrm{PE}$ per tonne of wet waste. 
This means that combustion of one tonne of waste has been reduced from amounting to $8 \%$ of the annual acidification potential for one person, to $0.3 \%$ of the annual potential. This is equivalent to a drop in air emission from $5.9 \mathrm{~kg}$ of $\mathrm{SO}_{2}$-equivalents per tonne of waste to $0.2 \mathrm{~kg}$ of $\mathrm{SO}_{2}$-equivalents per tonne of waste. The reason for the growing potential impact from global warming is due to the increased use of electricity and chemicals in the APC system, it has to be kept in mind that this figure does not take recovery of energy into account which else would negate this use of electricity as discussed later in section 6.2. The largest reduction is seen for the impact potential human toxicity via air, which in PE has dropped from 14 to 0.08 ; a difference of a factor 174 . The emissions contributing to eco-toxicity in soil were so small that they were exempted from the figure as they would not show up. The various impacts are linked to characteristic substances: acidification is mainly affected by the changes in the removal efficiency of $\mathrm{NO}_{\mathrm{X}}$ and $\mathrm{HCl}$ and to a lesser extent to the efficiency improvements for $\mathrm{SO}_{2}$ removal. Global warming is mainly from the combustion of carbon of fossil origin, as well as from the ancillary material production. Nutrient enrichment is only affected by changes in $\mathrm{NO}_{\mathrm{X}}$ concentrations. For the toxicity related impacts it is the heavy metals concentrations causing the impacts, mainly mercury, cadmium and lead.

To give a better understanding of the size of the impacts it can be considered that the functional unit of 1 tonne of waste corresponds approximately to the average municipal solid waste generation by two people in Denmark (OECD, 2002).

Table 5 shows the relative impact of waste incineration per person estimated for an incinerator with no APC technology (APC1) and an incinerator with the best available APC technology (APC8). This shows how dramatic the improvement in flue gas cleaning technologies has been for waste incinerators during the last 35 years. 
Considering the values for APC 8 it can be seen that the environmental impacts of incinerating the solid waste generated by one person constitutes less than $3 \%$ of the total environmental impact of a person no matter which environmental impact is considered. Furthermore it has to be remembered that the energy most likely will be recovered and substitute emissions taking place elsewhere.

Table 5 Impact potential given in Person Equivalent (PE) per person for APC1 and APC8 which are the worst and the best air pollution control technology, respectively. One person is assumed to generate $500 \mathrm{~kg}$ of municipal waste per year.

\begin{tabular}{lccc} 
& $\begin{array}{c}\text { APC 1 } \\
\text { PE / Person }\end{array}$ & $\begin{array}{c}\text { APC 8 } \\
\text { PE / Person }\end{array}$ & $\begin{array}{c}\text { Factor } \\
\text { Difference }\end{array}$ \\
\hline Global Warming & 0.0176 & 0.0208 & 0.85 \\
Nutrient Enrichment & 0.0125 & 0.0010 & 12 \\
Acidification & 0.0405 & 0.0014 & 29 \\
Eco-toxicity in Water & 0.2324 & 0.0119 & 20 \\
Human Toxicity via Soil & 0.5011 & 0.0081 & 62 \\
Human Toxicity via Air & 0.9976 & 0.0286 & 35 \\
Human Toxicity via Water & 0.0730 & 0.0004 & 174 \\
\hline
\end{tabular}

Overall it can be seen that there has been a drastic change in the emissions from waste incinerators. The waste incinerators back in the 70 ies did have significant emissions to the environment, but the data also shows that today's waste incinerators have a very low impact on the environment. Although this study does not include the solid residues from waste incineration (bottom ashes, APC residues, waste water sludge, etc.) it is acknowledge that these residues exist and that with the increasing air pollution control technology especially the amount of APC residue increases significantly. However, these residues can all to a large extent be controlled with a minimum of emissions to the environment.

\subsection{Importance of energy recovery}

In addition to the development of APC technologies, there has been a substantial improvement in the energy recovery from waste incinerators. 
Figure 2 shows the importance of this improvement by combining the waste incineration scenario APC8 with the energy recovery technologies presented in Table 2 assuming that energy substituted was based on coal and natural gas (Table 3), respectively. The emissions contributing to eco-toxicity in soil were so small that they were exempted from the figure as they would not show up.

Figure 2 Standard and toxic environmental impact potentials in Person Equivalents (PE) showing the importance of energy recovery rate and type of recovery (heat/electricity), exemplified with coal and gas substitution.
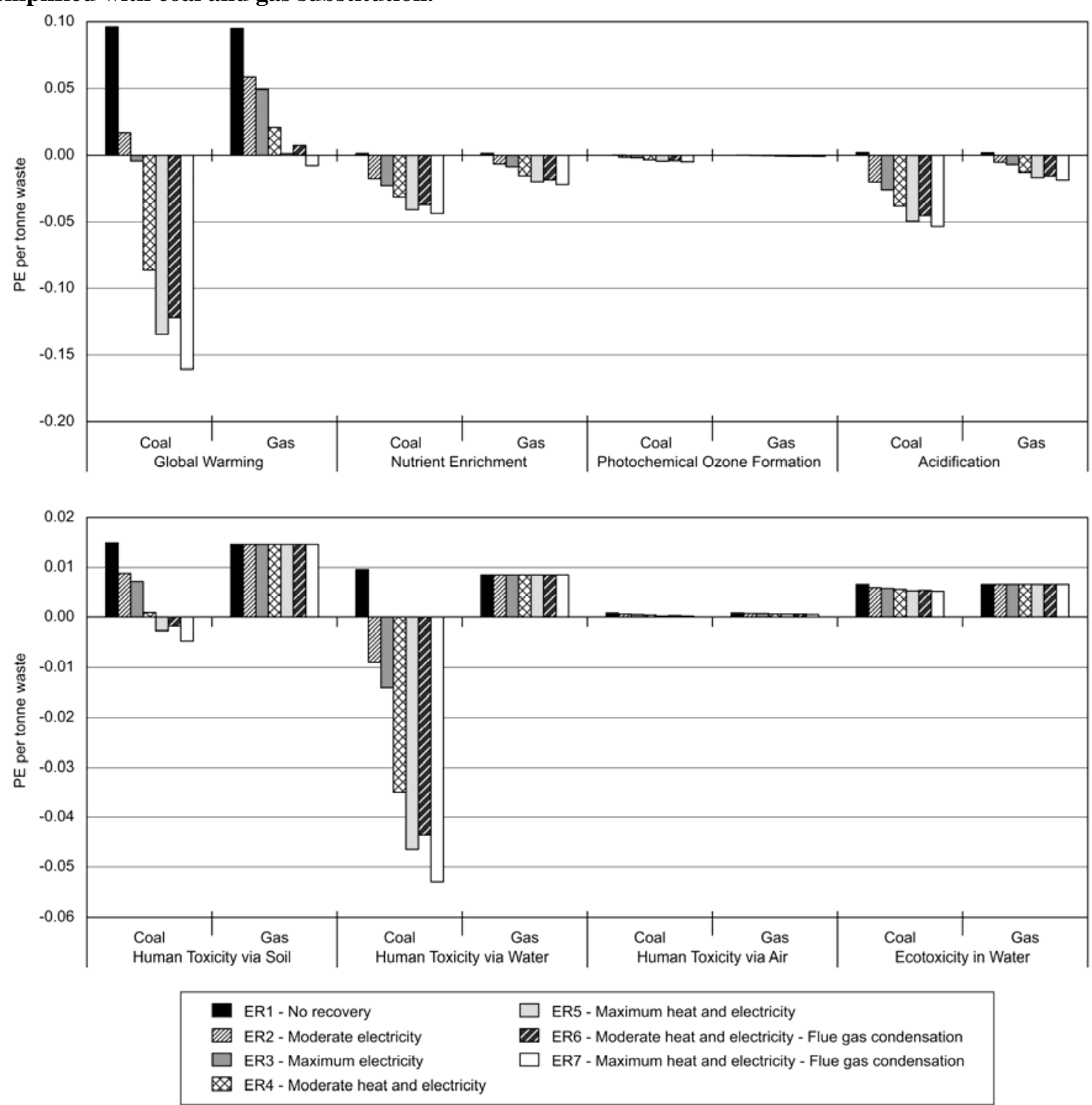

Figure 2 and 3 show that for the "no energy recovery" scenario (ER1) a net emission release to the environment is seen, since the system is not credited any avoided emissions. But as soon as there is just a moderate recovery of energy almost 
all impact categories show an overall saving. The exception to this is for the toxic categories where the natural gas energy is cleaner than energy based on waste incineration, so the emissions from waste incineration can here only be partly offset. For global warming a part of the reason for the large savings is that only a part of the incinerated waste is of fossil origin and therefore contributing to the global warming potential, whereas the organic waste is not contributing (see Christensen et al., 2009). Additionally, it can be seen that the savings are significantly higher when recovering both heat and electricity as opposed to only recovering electricity. This is due to a gross energy recovery efficiency of $75 \%$ or more (see Table 3 ), when heat is also utilized, whereas the maximum electricity recovery rate is $25-30 \%$ as the steam parameters have to be kept at a certain level to avoid corrosion (Ragossnig et al , 2008). The same trend is seen for the other impact categories, both standard and toxic impact categories. However, it must be kept in mind that the reason for these large savings is the recent reductions in stack emissions of today's waste incinerators, and by just going back to the designs from before 2004 several impact categories showed overall loads to the environment.

It is clear that the choice of fuel type substituted can have as much of an influence as the energy recovery rate of the waste incinerator itself. It is consequently very important to establish what the substituted energy source is. For heat this is very locally determined as heat cannot be transported over large distances, consequently the marginal heat should be identified for each specific area or based on aggregated values if the specific location of the waste incinerator is unknown (Sahlin et al., 2004). Electricity, on the other hand, is distributed via large interconnected networks across national borders, and electricity on the grid is produced from various sources. Consequently, it may be difficult to identify which technology and fuels are actually 
affected by a change in electricity demand. It is therefore important to assess which consequences the uncertainty of the marginal electricity has for the overall result (see e.g. Astrup et al., 2009). This could be done by running a number of different scenarios substituting various energy technologies and fuels. If they all point to a net saving this will provide a more robust result compared with investigating only a single energy source.

\subsection{General comments}

The significant development in APC technologies and energy recovery shows that waste incineration has moved from waste disposal plants to waste-to-energy plants, and waste incinerators have gone from being net emitters to the environment, to be net savers where significant energy recovery can be achieved. This emphasizes the importance of using the best available technologies when performing LCAs of wasteto-energy in future waste management systems. It is not sufficient to use whichever data are available in general LCA databases, since data older than 10 years may give a very misleading picture of waste incineration. This is of course also the case for other waste disposal options where there has been a large development in emission control and efficiency improvements.

\section{Conclusion}

Waste incineration has developed from waste disposal plants to waste-to-energy plants. It can be seen that with the introduction of today's extensive air-pollutioncontrol the emissions released from waste incineration plants are not significant and waste incineration can therefore be considered a valid option for solid waste 
management. Furthermore it is found that plants with a high energy recovery likewise have made waste incineration an attractive source of renewable energy if a significant fraction of the produced energy can be utilized. 


\section{References}

Astrup, T., 2009. Estimating contents of biogenic and fossil carbon in municipal solid waste. In: Proceedings Sardinia 2009 - Twelfth International Waste Management and Landfill Symposium, S. Margherita di Pula, Cagliari, Italy.

Astrup, T., Møller, J. \& Fruergaard, T., 2009b. Incineration and co-combustion of waste: accounting of greenhouse gases and global warming contributions. Waste Management \& Research, 27, 789-799.

Christensen, T. H., Gentil, E., Boldrin, A., Larsen, A., Weidema, B., Hauschild, M., 2009. C balance, carbon dioxide emissions and global warming potentials. Waste Management \& Research, 26, 1-9.

EDIP (Environmental Design of Industrial Products), 2004. Life cycle assessment Database Developed by the Danish Environmental Protection Agency in 1996, 2nd update. EDIP, Copenhagen, Denmark.

European Parliament, 2000. EU waste incineration directive. Directive 2000/76/EC of the European Parliament and of the Council of 4 December 2000 on the Incineration of Waste. Official Journal of the European Union, L 332, 91-111.

Fruergaard, T., Ekvall, T. \& Astrup, T., 2009. Energy use and recovery in waste management and implications for accounting of greenhouse gases and global warming contributions. Waste Management \& Research, 27, 724-737.

Kirkeby, J.T., Hansen, T.L., Birgisdóttir, H., Bhander, G.S., Hauschild, M.Z., Christensen, T.H. 2006. Environmental assessment of solid waste systems and technologies: EASEWASTE. Waste Management \& Research, 24, 3-15.

Nielsen, M., Illerup, J.B., 2003. Emissionsfaktorer og emissionsopgørelse for decentral kraftvarme. Eltra PSO projekt 3141. Kortlægning af emissioner fra decentrale kraftvarmeværker. Delrapport 6. (Emission factors and accounting for 
decentralized heat and power. Assessment of emissions from decentralized heat and power plants, in Danish, with an English summary). Faglig rapport fra DMU nr. 442. Danmarks Miljøundersøgelser, Århus Universitet, Århus, Denmark.

OECD (Organisation for Economic Co-operation and Development), 2002. OECD Environmental Data Compendium 2002, Public Affairs Division, OECD, Paris, France.

Ragossnig, A.M., Wartha, C., Kirchner, A., 2008. Energy efficiency in waste-toenergy and its relevance with regard to climate control. Waste Management \& Research, 26, 70-77.

Riber, C., Fredriksen, G.S., Christensen, T.H., 2005. Heavy metal content of combustible municipal solid waste in Denmark. Waste Management \& Research, $23,126-132$.

Riber, C., Bhander, G.S., Hauschild, M., Christensen, T.H., 2008. Environmental assessment of waste incineration in a life-cycle-perspective (EASEWASTE). Waste Management \& Research, 26, 96-103.

Sahlin, J., Knutsson, D., Ekvall, T., 2004. Effects of planned expansion of waste incineration in the Swedish district heating systems. Resources, Conservation and Recycling, 41, 279-292.

Stranddorf, H.K., Hoffmann L., Schmidt, A., 2005. Impact Categories, normalization and weighting in LCA - Update on selected EDIP97-data. Environmental news No. 78. Copenhagen, Denmark: Danish Environmental Protection Agency, Danish Ministry of the Environment; 2005.

Wenzel, H., Hauschild, M., Alting, L., 1997. Environmental Assessment of Products. Volume 1: Methodology, tools and case studies in product development. Published by Chapman \& Hall, 2-6 Boundary Row, London, UK 